Yahong Xue* and Qianqiu Xu

\title{
An ecological discourse analysis of news coverage of COVID-19 in China in The Times and The New York Times
}

https://doi.org/10.1515/jwl-2021-0005

Received August 26, 2020; accepted February 24, 2021; published online July 23, 2021

Abstract: The COVID-19 pandemic, as a public health emergency of international concern, is the most extensive one to afflict humanity in this century and poses a grave threat to human life and health. Facing this unknown, unexpected and devastating disease, China makes an all-out effort to fight against it shoulder to shoulder with the rest of the world. Based on the ecosophy of "diversity and harmony, interaction and co-existence" and with ecolinguistic appraisal system as the theoretical framework, this study provides an ecological discourse analysis of news coverage of COVID-19 in China in The Times and The New York Times, two major Western mainstream media outlets, aiming to reveal the appraisal characteristics and ecological orientations of the news coverage on this public health emergency as well as the attitudes of the two major Western mainstream media outlets concerned towards China's fight against COVID-19, thus helping people to understand the news discourse on this major public health emergency and in turn to distinguish different media positions. It is found that both news outlets employ more negative appraisal resources to express their attitudes towards China's fight against COVID-19 and their news coverage is to a greater extent eco-destructive.

Keywords: COVID-19; ecological discourse analysis; ecological orientation; news coverage; public health emergency

\section{Introduction}

In late December, 2019, doctors identified a cluster of pneumonia cases which seemed to have been caused by a previously unknown virus. The virus

*Corresponding author: Yahong Xue, College of Foreign Languages, Jilin University, Changchun, China, E-mail: xueyh@jlu.edu.cn

Qianqiu Xu, College of Foreign Languages, Jilin University, Changchun, China,

E-mail: xuqianqiu@jlu.edu.cn

๑ Open Access. ( 2021 Yahong Xue and Qianqiu Xu, published by De Gruyter. (c) BY licensed under the Creative Commons Attribution 4.0 International License. 
spread rapidly and widely and was declared a public health emergency of international concern on January 31, 2020 and named Corona Virus Disease 2019 (COVID-19 for short) by the World Health Organization (WHO) on February 11. The outbreak not only posed a grave threat to human life and health but also brought daunting challenges to economic development, social stability, and even global politics.

COVID-19 in China has engaged considerable attention from the media and received mounting news coverage in mainstream media worldwide. Based on a review of the relevant studies, this paper conducts an ecological discourse analysis of news coverage of COVID-19 in China in The Times and The New York Times, two major Western mainstream media.

\section{Literature review}

Since its outbreak, the COVID-19 pandemic has captivated the attention of the academia and prompted a multitude of relevant studies from different perspectives.

Studies of the COVID-19 pandemic in China mainly focus on information release and guidance of public opinion (Gao and Zhao 2020; Li and Wang 2020; Li and Zhang 2020), identity to the Chinese nation and response to nationalism in the background of the prevention and control of COVID-19 outbreak (Peng 2020), the cognitive power of deliberate metaphors in the reports of the outbreak (Zhang and Wang 2020), the discursive construction of community identity in combating the outbreak (Miao and Li 2020), a discourse study of traditional Chinese medicine and Western medicine joint treatment of COVID-19 (Tian 2020), issues concerning emergency language and emergency language competence (Li and Rao 2020; Li and You 2020; Wang et al. 2020; Wang and Sun 2020), the practice of and reflections on "Epidemic Language Service Corps" (Li et al. 2020), and the role of language in responding to public emergencies (Liu et al. 2020).

Western studies, on the other hand, so far are concerned mostly with the epidemiology and pathogenesis of the outbreak (Hussin and Byrareddy 2020), early dynamics of its transmission and control (Kucharski et al. 2020), the relationship between COVID-19, SARS and MERS (Petrosillo et al. 2020), and media coverage of the COVID-19 pandemic and financial markets behavior in its shadow (Haroon and Rizvi 2020).

As can be seen from the above review, the COVID-19 pandemic has become a topic of general interest in the academia and a rich array of relevant studies have been conducted from such perspectives as epidemiology, pathogenesis, linguistics as well as journalism and communication, which offer deep insights 
into the different aspects of this pandemic. However, little study has been conducted on the relevant news coverage of the outbreak, still less linguistic study on mainstream media coverage of COVID-19 in China, rendering the relevant topics of appraisal characteristics of the coverage and the attitudes of the news outlets left rarely touched upon.

For most people worldwide, news media are a principal source of information about current affairs, both domestic and international. And the information provided by them plays a key role in the construction of our pictures of reality. Moreover, it is the total set of information provided by the news media that influences these pictures (McCombs 2014: 72). This role of the news media in identifying the key issues and topics of the day and their ability to influence the salience of these issues and topics on the public agenda has come to be called the agenda-setting role of the news media (McCombs 2014: 55). Agenda setting focuses on guiding readers' attention, which reflects the importance of media's social responsibility and the social intervention power of agenda setting (Miao and Zhao 2019: 1-10). As a medium of meaning communication, news coverage can also embody the reporters' judgments as well as the attitudes of the news outlets towards the relevant events. In this sense, it is of vital importance to study the news coverage of COVID-19 in China in Western mainstream media to probe the characteristics of the appraisal resources and ecological orientations of the news coverage under discussion.

Ecological discourse analysis (EDA for short), as a central approach in ecolinguistics, emerges in the context of frequent global environmental crisis and involves the analysis of all types of discourses, including those discourses about environment or ecological concerns as well as other discourses, "which have the potential to encourage people to behave in ways which damage or preserve ecological systems" (Alexander and Stibbe 2014: 109). To be more specific, the purposes of EDA are to explore the relationship and interaction between language and ecology, reveal the ecological orientations of all types of discourses and judge them as eco-destructive, eco-ambivalent, or eco-beneficial discourses. Eco-destructive discourses are those that convey ideologies that strongly oppose multiple aspects of the "Living" ecosophy (Stibbe 2015: 13). Eco-ambivalent discourses have a positive aim of dealing with some of the ecological problems caused by destructive discourses, but they arise from the same society as the destructive discourses and may be influenced by political or commercial interests. And eco-beneficial discourses are those that convey ideologies which can actively encourage people to protect the systems that support life (Stibbe 2015: 29-33).

Since EDA can help enhance the harmonious relationship between human beings, between human and other species, between human and nature, and between language and the ecosystem by reference to the agentive role of language in 
constructing reality (Huang and Zhao 2017: 585-596), we will conduct an EDA of the news coverage of COVID-19 outbreak in China in two Western mainstream media to probe their ecological orientations and judge whether the news stories are ecologically beneficial, ambivalent, or destructive.

\section{Theoretical foundation}

\subsection{Ecosophy of "diversity and harmony, interaction and co-existence"}

Ecosophy, a shortening of "ecological philosophy”, is used by Naess (1995: 8) to mean:

[...] a philosophy of ecological harmony [...] openly normative it contains norms, rules, postulates, value priority announcements and hypotheses concerning the state of affairs [...] The details of an ecosophy will show many variations due to significant differences concerning not only the "fact" of pollution, resources, population, etc. but also value priorities. (Naess 1995: 8)

"Since the ecosophy includes 'norms' and 'value priority announcements' there is not one universal 'correct' ecosophy that ecolinguistics should be based on" (Stibbe 2015: 12). When doing an EDA, ecolinguists should take the ecosophy they hold dear as the criterion to guide their analysis and make judgment on the type of discourse.

Based on previous studies, He and Wei (2018: 28-35) proposes the ecosophy of "diversity and harmony, interaction and co-existence" to guide international ecological discourse analysis. "Diversity and harmony, interaction and co-existence", principles by which China seeks to practice diplomacy, mean that we should respect the diversity of world civilization and establish the idea of harmonious co-existence of one another.

Virus knows no borders and is the common enemy of mankind, who lives in a global village now where harmony and co-existence are the best policy. Facing the COVID-19 pandemic, all mankind should go hand in hand and cooperate with each other to fight against it. And we can only succeed when each and every individual becomes part of the containment strategy and each and every country concerned makes due effort in the context of constructing a global community with a shared future for all mankind. In the present study, we follow the ecosophy of "diversity and harmony, interaction and co-existence" as a criterion to guide the EDA of news coverage of COVID-19 in China in The Times (TT for short) and The New York Times (NYT for short). 


\subsection{Ecolinguistic appraisal system}

In the analysis of news coverage of the 19th National Congress of the Communist Party of China in the Australian mainstream media, He and Ma (2019: 1-9) constructs an ecolinguistic appraisal system based on the ecosophy of "diversity and harmony, interaction and co-existence”. It develops from the appraisal system which takes systemic functional linguistics as the theoretical framework and is a system of interpersonal meaning. Appraisal is concerned with evaluation - the kinds of attitudes that are negotiated in a text, the strength of the feelings involved and the ways in which values are sourced and readers aligned (Martin and Rose 2007: 17). Ecolinguistic appraisal system focuses on two dimensions: one is object and attribute; the other is lexicogrammatical resources. The former constitutes a macro-evaluation system, with the concept of agenda setting put in it at the discourse level, and the latter a micro-evaluation system.

The macro-evaluation of news coverage should follow the following criteria: in a discourse or a series of discourses on a certain topic, if each object and attribute is covered comprehensively and the proportion of relevant topics is appropriate, that is, it follows the ecosophy of "diversity and harmony, interaction and co-existence", it is beneficial agenda. If the proportion is not appropriate, that is, it does not fully follow the ecosophy of "diversity and harmony, interaction and co-existence", it is vague or neutral agenda. And if the objects and attributes involved in the discourse are not covered comprehensively, that is, it violates the ecosophy of "diversity and harmony, interaction and co-existence", it is destructive agenda (He and Ma 2019: 1-9).

The micro-evaluation system, on the other hand, involves the evaluation function at the lexicogrammatical level. It consists of three subsystems: attitude, engagement, and graduation. Attitude is concerned with our feelings, including emotional reactions, judgments of behavior and evaluation of things. Engagement deals with sourcing attitudes and the play of voices around opinions in discourse. Graduation attends to grading phenomena whereby feelings are amplified and categories blurred (Martin and White 2005: 34-38). He and Ma (2019: 1-9) expands the attitude at the lexicogrammatical level by putting the three characteristics of emotional origin, judgment criteria, and objects of appreciation in it.

Ecolinguistic appraisal system can be used in the analysis of news coverage, which will provide an operable theoretical framework for the researchers to guide their analysis of the ecological and non-ecological factors in the news discourse and explore the ecological orientations embodied in it. We adapt this ecolinguistic appraisal system in the EDA of the news coverage of COVID-19 in China in TT and NYT, two major Western mainstream media outlets. In the micro-evaluation, we 
follow Martin and White's appraisal system, while in macro-evaluation, we take He and Ma's macro-evaluation system as the theoretical framework.

\section{Research design}

\subsection{Research questions}

With the ecosophy of "diversity and harmony, interaction and co-existence" and ecolinguistic appraisal system as the theoretical foundation, this paper conducts an EDA of the news coverage of COVID-19 in China in TT and NYT, aiming to answer the following two research questions:

1. What are the appraisal characteristics in the news coverage of COVID-19 in China in the two media?

2. What are the ecological orientations of the news coverage of COVID-19 in China in the two media and what are their attitudes towards China's fight against it?

\subsection{Data collection}

The data employed in this study come from $\mathrm{TT}^{1}$ and $\mathrm{NYT}^{2}$, two major Western mainstream media outlets.

TT and NYT are selected as data sources for the reason that these two newspapers are widely considered in the West as good representatives of high-quality newspapers. Many people in the West, particularly those who consider themselves educated, liberal-minded, and middle class, believe these two newspapers are credible and authoritative news sources. How they cover a certain event can very much influence how it is viewed by mainstream Western community. To be more specific, The Times, known as "the faithful recorder of British society", has always been regarded as the first mainstream newspaper in Britain, which plays a prominent role in British domestic politics and international relations and has a great influence on politics, economy, and culture all over the world. Similarly, more than any other U.S. news medium, The New York Times has become crucial reading for those interested in the news, national politics, and international affairs (Lule 2001: 6). And it is considered a key gatekeeper to national and international news coverage, with most other newspapers and television news outlets following what it emphasizes (Benoit et al. 2005; Blakely 2003; Denham 2014; Jason and Capellan

1 www.thetimes.co.uk.

2 www.nytimes.com. 
2019: 1312-1341; Lule 2002). There has been much news coverage of the COVID-19 pandemic and China's fight against it in these two media outlets, which, to a greater extent, reflects their and their readers' views and understanding of the topic.

In selecting which news stories to analyze, we first identified four major incidents of the outbreak: the announcement by Wuhan City government that a local outbreak has been identified (December 30, 2019); the lockdown of Wuhan (January 23, 2020); the opening of the first mobile cabin hospital (temporary treatment center) to treat the infected in Wuhan (February 6, 2020); and the re-opening of Wuhan (April 8, 2020). We decide to study all news coverage concerning China's COVID-19 outbreak on the dates identified as well as the following day, considering the time difference. However, neither TT nor NYT covered the outbreak in 2019. NYT's first outbreak story appeared in the newspaper on January 6, 2020 and TT's on January 8, 2020. So for the beginning of the outbreak, we selected news stories from the two newspapers from January 6 to January 10, 2020. Altogether 30 pieces of news reports were collected, 14 from TT and 16 from NYT respectively, the total number of words being 8,046 in the former and 16,560 in the latter. With the collected data, two corpora are set up accordingly.

\subsection{Data annotation}

After the collection of the data, UAM Corpus Tool $3.3^{3}$ is used as the analytical tool to annotate the appraisal resources employed in the data to ensure the objectivity and correctness of the analysis results. This tool takes the task to be annotated as a project, in which each operation once saved can be stored. In the present study, two projects are set up, one with the data from TT and the other the data from NYT. Then the different appraisal resources in the two projects are identified and annotated manually with reference to Martin and White's (2005) discussion of appraisal system.

After the manual annotation of the data, which is double checked by two other researchers expert at the application of the appraisal system to justify the results of the annotation, descriptive statistics are used to analyze the appraisal resources employed in the relevant news coverage. The analysis is made first to explore appraisal characteristics in the data in the micro-evaluation system and probe the ecological orientations embodied in the use of these appraisal resources and then to examine the attitudes of the two media towards China's fight against the

3 http://www.corpustool.com/download.html. 
COVID-19 pandemic in the macro-evaluation system in terms of the objects and attributes embodied in the news coverage.

\section{Data analysis and discussion}

In this section, we will first carry out a micro-evaluation analysis of the evaluation function of the appraisal resources at lexicogrammatical level, and then move to a macro-evaluation analysis at discourse level focusing on the objects and attributes covered in the two media outlets concerning COVID-19 in China.

\subsection{Analysis in the micro-evaluation system}

The annotation of the data in the two corpora identifies the general distribution of appraisal resources used in the two media outlets, as is shown in Table 1.

As is illustrated in Table 1, all the three types of appraisal resources are used in the news coverage of COVID-19 in China in the two media outlets. There are altogether 700 and 2,053 appraisal resources employed in TT and NYT respectively, with the use of engagement resources and attitudinal resources ranking the first accounting for 48.00 and $48.32 \%$ respectively in the two corpora, and that of graduation resources ranking the last. The use of these appraisal resources can reflect the attitudes of the reporters and the media outlets toward China's fight against the COVID-19 pandemic. Here we will explore the characteristics of attitudinal resources first, followed by those of engagement resources and graduation resources.

Table 1: Distribution of appraisal resources employed in the data.

\begin{tabular}{llrrrrrr}
\hline Source & & \multicolumn{2}{c}{ TT } & & \multicolumn{2}{c}{ NYT } \\
\cline { 7 - 8 } \cline { 7 - 8 } Feature & & & Number & Percent & & Number & Percent \\
\hline Appraisal system & Attitude & & 185 & $26.43 \%$ & & 992 & $48.32 \%$ \\
& Engagement & & 336 & $48.00 \%$ & & 676 & $32.93 \%$ \\
& Graduation & & 179 & $25.57 \%$ & & 385 & $18.75 \%$ \\
Total & & 700 & $100 \%$ & & 2053 & $100 \%$ \\
\hline
\end{tabular}




\subsection{Characteristics of attitudinal resources}

Attitude, as one subsystem of the appraisal system, is concerned with our feelings, including emotional reactions, judgments of behavior, and evaluation of things, which consists of three subsystems: affect, judgment, and appreciation, each of which can be positive or negative. Affect deals with resources for construing emotional reactions. Judgment is concerned with resources for assessing behavior according to various normative principles. And appreciation looks at resources for construing the value of things (Martin and White 2005: 35-36). In the news coverage of COVID-19 in China in the two media, all the three sub-types of attitudinal resources are employed, the distribution of which is shown in Table 2.

As can be seen from Table 2, judgment resources rank the first, accounting for a much higher percentage in the data in both newspapers. Next come appreciation resources and affect resources rank the last. The preferred use of judgment resources and appreciation resources to that of affect resources in the data attests the journalistic practice that journalists tend to use more judgment and appreciation resources than emotional resources in expressing their attitudes, which reflects their pursuit of objectivity in news reports. However, in terms of the positive and negative attitudinal resources employed in the data, the negative attitudinal resources enjoy a higher percentage in the two media. In NYT, negative attitudinal resources account for $35.88 \%$ of the total attitudinal resources used, almost three times as much as that of positive attitudinal resources which account for $11.98 \%$, while in TT, negative attitudinal resources account for $18.14 \%$, twice that of the positive ones. But in terms of the sub-types of the attitudinal resources employed in TT, the proportion of positive affect is higher than that of the negative affect, while the proportion of the positive appreciation is almost same as that of the negative appreciation, which is quite different from the scenario in NYT.

Table 2: Distribution of attitudinal resources in the data.

\begin{tabular}{llllll}
\hline Source & & TT & & NYT & \\
\hline Attitudinal & Type & Positive & Negative & Positive & Negative \\
Resources & Affect & $8 / 1.14 \%$ & $4 / 0.57 \%$ & $5 / 0.24 \%$ & $48 / 2.34 \%$ \\
& Judgment & $41 / 5.86 \%$ & $115 / 16.43 \%$ & $163 / 7.94 \%$ & $446 / 21.72 \%$ \\
& Appreciation & $9 / 1.29 \%$ & $8 / 1.14 \%$ & $78 / 3.80 \%$ & $252 / 12.27 \%$ \\
Total & & $58 / 8.29 \%$ & $127 / 18.14 \%$ & $246 / 11.98 \%$ & $746 / 35.88 \%$ \\
\hline
\end{tabular}


Looking through TT and NYT coverage of COVID-19 in China, it is clear that on the whole NYT is more hostile towards the Chinese government and is more suspicious of Chinese official information and statistics. However, it is interesting to note that NYT coverage at the beginning of the outbreak was more informative and less eco-destructive.

Both newspapers first covered the outbreak in Wuhan in January, NYT on January 6 and TT on January 8. From the beginning, it is plain to see that NYT coverage is more detailed with the first report of the outbreak consisting of 1,032 words compared with TT's, which is a short one with only 70 words. It is very likely due to the fact that TT is now a smaller sized newspaper with more limited space. A closer look at the stories we selected shows that NYT concentrated much more personnel and resources on the coverage of COVID-19 in China than TT, whose COVID-19 stories often contain more contents about pandemic situation within the UK or Europe. Most TT stories are often the work of only one or two reporters, whereas NYT stories often have many more contributors based in multiple locations. However, we can also see from Table 2 that NYT stories contain a much greater proportion of negative messages than TT stories.

The earliest TT coverage of the outbreak "Chinese Mystery Virus Warning to US Tourists" came on January 8, as is shown in Example (1).

Example (1)

Americans in China should avoid animals and contact with sick people as the country deals with a mysterious pneumonia outbreak, the US embassy there has said. The virus was first reported in Wuhan, a central city of 11 million people, last month and there have been at least 59 cases. Rumors of a return of the highly contagious Sars virus were discounted. (TT January 8, 2020)

In this coverage, the outbreak is first reported by employing the grammar of reported speech "[...], the US embassy there has said." Then the location of the outbreak as well as the number of cases are described, followed with a monogloss saying that "Rumors of a return of the highly contagious SARS virus were discounted." This brief coverage of the outbreak is informative and is, to some extent, also negative, since negative appreciation resources "mystery" and "mysterious" are used in the headline and the report itself respectively to describe the origin of the outbreak, which reveals the reporter's misconception of the origin of the outbreak and stigmatization of China. Actually, tracing the origin of novel corona virus is a complex scientific issue. The WHO and the international community are clearly opposed to linking the virus with specific countries and regions and to stigmatization. 
The earliest NYT coverage of the outbreak came on January 6, two days earlier than that of TT. It talked about the Chinese government "racing to identify a new illness", showing the positive attitude towards the actions taken by it. The report's writers, the main one being actually the same NYT reporter who wrote the very negative story dated April 9, are restraint in expressing personal judgment at this juncture. They also used quotes from a medical expert to explain the difficulty of dealing with this new disease, as can be illustrated by Example (2) taken from the excerpt.

Example (2)

Chinese health officials at first appeared to be closely guarding information about the illness. [...] But more recently, the government appeared to be moving more quickly to disclose information about new cases in a sign that it has learned its lesson from SARS, said Leo Poon, a public health expert at the University of Hong Kong. "I have to emphasize this is a new disease, and no one on Earth has gone through this before," he said. (NYT January 6, 2020)

From Example (2), it is clear that the writers consciously tried to balance the report, listing government wrong doings and following it with observations of positive developments from experts.

This report consists of 21 paragraphs, the first two centered on the personal experience of one particular patient, Mr. Li. Then in paragraph three, the writers gave a positive appreciation at the beginning but followed it with negative appreciations.

The cases have alarmed Chinese officials, who are racing to unravel the mystery behind them in a region where the memory of an outbreak of the dangerous respiratory disease known as SARS remains fresh. (NYT January 6, 2020)

Here the writers first used "racing to unravel" to indicate that Wuhan officials are responding to this public health emergency in a timely manner, but then followed it with a reference to the SARS outbreak. In the next paragraph, the writers gave some background information on SARS and the first negative and thus ecodestructive reference of China:

SARS originated in China and killed more than 800 people worldwide in 2002 and 2003. At the time, the Chinese government tried to cover up the problem, which is exacerbating fear now about this new illness. (NYT January 6, 2020)

Similar eco-destructive reference was given in TT coverage of China's fight against the COVID-19 pandemic on January 24, in which China's measure to lockdown five Chinese cities to stem the spread of the virus was described by using negative 
appreciations "unprecedented", and the residents of Wuhan were given "just a few hours' notice". Then the writer moved on saying that: "Compared with the prolonged cover-up of the SARS outbreak, the authorities have been relatively open about the epidemic. There are suspicions, however, that there are many more cases of the coronavirus than the official tally." (TT January 24, 2020) The last sentence also lends support to TT reporter's suspicion of the official statistics of the corona virus cases.

But at this point one can still argue that it is regular journalistic background information giving and indeed it was true that certain levels of the Chinese government were not open and transparent enough at the beginning of the SARS outbreak. However, if we buy into that narrative we would be falling for a common trap because then we would be accepting that all actions taken by all Chinese officials, regardless of their position or rank, are government-sanctioned or by order from the top officials in Beijing. That assumption is based on and, in turn, contributes to the bias that the Chinese government is authoritarian and controlling, because otherwise how can the tens of millions of government officials and workers in China all toe the government's line?

Over time, NYT coverage of China's fight against the COVID-19 pandemic became increasingly negative. When the cabin hospitals started to receive patients in Wuhan on February 6, NYT coverage the day after described it as an "extreme measure", and talked about government workers doing "house-to-house search", "rounding up" patients who were then "herded" and "warehoused" in "quarantine camps". The use of these negative words, either deliberately chosen or unconsciously selected, cannot help but to evoke the horror of the Holocaust in the minds of NYT readers, many of whom would be Jewish. In the same report, the writers also wrote that Wuhan is in the middle of a "worsening humanitarian crisis" with a "staggeringly" high death rate, "dwindling medical supplies", and possible imminent food shortage. For this story, the reporter talked to two experts, one an infectious disease specialist based in the United States, and the other an academic from the Chinese University of Hong Kong who specializes in China studies. The medical expert is appreciative of the scale of the challenge that China was facing with the outbreak in Wuhan but had some doubts over how the cabin hospitals would be run and how effective they would be on an academic level. The China studies expert was quoted saying that Wuhan was suffering a "humanitarian crisis" and the people were "left high and dry". Reading this coverage, it would be hard for the average NYT reader to think of the cabin hospitals in a positive light as they would have been led to believe that those were just places where sick people were just left to fend for themselves.

Actually, ever since the outbreak of the pandemic, American politicians, especially those of the Trump Administration, have repeatedly blamed China for its 
spread. They keep referring to it as "the Wuhan virus" or "the Chinese virus", question China's pandemic prevention and control measures and statistics, and speak of China or the Chinese government as authoritarian, which can be seen in the following examples, taken from relevant news coverage of NYT, in which the negative attitudinal resource "authoritarian" is repeatedly used, demonstrating the negative attitude of NYT towards China system and the leadership of the Communist Party.

Example (3)

People here and across much of Hubei Province are subjects of a vast medical experiment conceivable only in authoritarian China [...]. (NYT February 6, 2020)

Example (4)

At the time, many outsiders saw it as an extreme step, one that could be tried only in an authoritarian system like China's. (NYT April 8, 2020)

Example (5)

China's critics, including the Trump administration, have blamed the Communist Party's authoritarian leadership for exacerbating the outbreak by initially trying to conceal it. (NYT April 9, 2020)

In a similar vein, TT also stigmatizes China by speaking of the virus as "Chinese mystery virus" in the headline of its report on January 8, "Chinese virus" on January 23, and "China Virus" on February 7 respectively. The use of these negative terms to address the corona virus reveals the negative attitude of TT reporters and the media outlet towards China.

Besides, let's look at Example (6), one excerpt from one of the four reports of COVID-19 in China on January 24 in TT.

Example (6)

Adam Kamradt-Scott, a global health specialist at Sydney University, has been monitoring the spread of the virus. While he applauds the Chinese government for taking "unusual and rare" measures to quell the spread of the infection, he is worried that it is too little, too late. "If the virus is already largely contained to Wuhan, this is a good public health measure to try to prevent and slow down the spread, particularly with the mass migration at Chinese new year. If the virus is already out of the bag and seeing community transmission in other cities, however, it’s effectively pointless and giving a false sense of security.” (TT January 24-2, 2020)

Here, Adam Kamradt-Scott is quoted to express an expert's attitude towards the measures taken by the Chinese government to contain the spread of the infection. 
On the one hand, positive appreciation resources, such as "unusual and rare" and "good" are used in this quotation to praise the measures taken by the Chinese government. On the other hand, negative appreciation resources "little," "late," "pointless," and "false" are also used to express his worry and construe implicitly the reporter's negative attitude towards the measures taken by the Chinese government.

Generally speaking, media, especially respected media, do not tell their readers or audience directly how they should think on any particular issue, as that not only goes contrary to what is generally believed to be good journalistic practice but may also lead to public dismay or even disdain. Rather, they contribute to how people see the world by presenting it in certain lights, thus giving themselves access to influence people's values, perceptions, priorities, and focus. It can be seen from the above examples that media outlets, and even respected media outlets such as TT and NYT, have also played a role in sending the same message to their readers and audiences, that the Chinese government is not to be trusted.

\subsection{Characteristics of engagement resources}

Engagement deals with sourcing attitudes and the play of voices around opinions in discourse, which, as the resources of intersubjective stance, can be divided into monogloss and heterogloss. Monogloss which involves no dialogistic alternatives offers only one stance and does not declare other stances. It expresses bare declarative and gets rid of other opinions. Heterogloss, on the other hand, admits other possible stances and opinions. The distribution of engagement resources in the data is shown in Table 3 and that of heteroglossic resources in Table 4.

As can be seen from Table 3, both monoglossic and heteroglossic resources are used in the relevant coverage in the two media, with heteroglossic resources accounting for a much higher percentage than monoglossic ones. In terms of the use of heteroglossic resources, as is illustrated in Table 4, the use of expansion takes up a higher percentage than that of contraction in the data in both media.

Table 3: Distribution of engagement resources in the data.

\begin{tabular}{|c|c|c|c|c|c|}
\hline \multicolumn{2}{|l|}{ Source } & \multicolumn{2}{|c|}{ TT } & \multicolumn{2}{|c|}{ NYT } \\
\hline & Type & Number & Percent & Number & Percent \\
\hline \multirow[t]{2}{*}{ Engagement resources } & Monogloss & 20 & $2.86 \%$ & 37 & $1.80 \%$ \\
\hline & Heterogloss & 316 & $45.14 \%$ & 639 & $31.13 \%$ \\
\hline Total & & 336 & $48 \%$ & 676 & $32.93 \%$ \\
\hline
\end{tabular}


Table 4: Distribution of heteroglossic resources in the data.

\begin{tabular}{|c|c|c|c|c|c|c|c|}
\hline \multicolumn{4}{|l|}{ Sources } & \multicolumn{2}{|c|}{$\mathrm{TT}$} & \multicolumn{2}{|c|}{ NYT } \\
\hline & Type & & & Number & Percent & Number & Percent \\
\hline \multirow{8}{*}{$\begin{array}{l}\text { Heteroglossic } \\
\text { resources }\end{array}$} & Contraction & Disclaim & Deny & 37 & $5.29 \%$ & 110 & $5.36 \%$ \\
\hline & & & Counter & 30 & $4.29 \%$ & 101 & $4.92 \%$ \\
\hline & & Proclaim & Concur & 8 & $1.14 \%$ & 0 & 0 \\
\hline & & & Pronounce & 1 & $0.14 \%$ & 0 & 0 \\
\hline & & & Endorse & 0 & 0 & 0 & 0 \\
\hline & Expansion & Entertain & & 99 & $14.14 \%$ & 140 & $6.82 \%$ \\
\hline & & Attribution & Acknowledge & 116 & $16.57 \%$ & 287 & $13.98 \%$ \\
\hline & & & Distance & 25 & $3.57 \%$ & 1 & $0.05 \%$ \\
\hline Total & & & & 336 & $48 \%$ & 675 & $32.93 \%$ \\
\hline
\end{tabular}

In journalism writing, it is stressed that the reporter should avoid giving opinions on matters, only giving facts so readers can reach their own conclusions and form their own opinions. Yet Table 3 shows that both TT and NYT stories contain monoglosses. Such monoglosses are often statements made with value judgment by reporter or reporters, a practice that is journalistically questionable and most likely done with the intention to influence the readers.

We can take a closer look at the NYT report "China, Citing Fewer Cases, Tries to Rewrite Its Role in Crisis", published on page A6 on April 9. The title of the report is already a monogloss, writing off China's effort to correct international misunderstandings and misinformation as attempts to rewrite history. Without looking at what is actually contained in the article, a reader has already been told that China is trying to do something which is wrong.

Let's take a look at Example (7), paragraph four of the article.

Example (7)

China's critics, including the Trump administration, have blamed the Communist Party's authoritarian leadership for exacerbating the outbreak by initially trying to conceal it. But China is trying to rewrite its role, leveraging its increasingly sophisticated global propaganda machine to cast itself as the munificent, responsible leader that triumphed where others have stumbled. (NYT April 9, 2020)

The message that this example contains has two layers: one factual and the other judgmental.

The factual layer: America's Trump administration believes that China has initially concealed information about the COVID-19 outbreak, resulting in the pandemic getting out of control. But China has denied that allegation and 
portrayed itself as a responsible country with useful epidemic-control experiences which it is willing to share with other countries.

The judgmental layer: China is ruled by communists. The Chinese regime is authoritarian. China tried to cover up the outbreak. Now China is trying to rewrite history. China is producing propaganda to change how people think. China is gloating over others' misery.

The judgmental layer, all monoglosses, is skillfully woven into the factual layer. Such writing will certainly influence some readers and how they think of China's role in the COVID-19 pandemic. It has to be pointed out that not all NYT stories included in this study are as eco-destructive as this particular piece, as this is by comparison one that is particularly judgmental and eco-destructive. It is written, it seems, with the intention to discredit China's COVID-19 experience and statistics.

Monoglosses used in TT reports also construe similar attitude, that is, to discredit China and the Chinese government. Consider by way of illustration, the use of monogloss in Example (1), the headline of TT first coverage of the outbreak “Chinese Mystery Virus Warning to US Tourists", which has been discussed above and Example (8), paragraph four in TT report on January 10:

\section{Example (8)}

Fears have been worsened because Beijing initially tried to hide the extent of the 2002 outbreak. The World Health Organization praised Beijing's response yesterday but said further investigation was needed to uncover "the source, modes of transmission, extent of infection and countermeasures implemented”. (TT January 10, 2020)

It can be found that compared with NYT ones, TT monoglosses, generally speaking, are less negative and therefore less eco-destructive.

The same is true in the use of heteroglossic resources in the data, which are of two categories: dialogistic contraction and dialogistic expansion, each of which has a number of more delicate subcategories to be drawn on for a more complete picture of appraisal. Attribution, as one sub-type of dialogistic expansion through the externalized proposition, is concerned with those formulations which disassociate the proposition from the text's internal authorial voice by attributing it so some external source. This is most typically achieved through the grammar of directly and indirectly reported speech and thought (Martin and White 2005: 111). Acknowledge, as one subcategories of attribution, associates the information being given with voices and/or positions which are external to that of the text itself and presents the writer as some sort of "informational fair trader" who simply conveys the views of others and who is therefore unimplicated in any relationship of solidarity which the reader may enter into with the quoted source whose 
viewpoint is being reported (Martin and White 2005: 115). In the present study, we find that in both TT and NYT coverage acknowledge accounts for a much higher percentage and a closer look at the reports shows that seven different kinds of external voices which can realize acknowledgement are employed to express the reporter's attitude indirectly, including governmental organizations/officials, non-governmental organizations/officials, experts, media, common people, corporation, and other sources, among which, government officials and experts are quoted or covered extensively to make the information appear more authoritative and convincing and at the same time to stand up for the reporters themselves helping them to implicitly express their evaluation of the event under discussion, as is illustrated by Example (1), (2), (5), (6), (7), and (8) above.

For another example, Jonathan Ball, of the University of Nottingham is quoted on TT coverage on February 7, saying that "We are at a key juncture in this outbreak and it is difficult to tell if the control efforts in China will be enough to bring this outbreak to an end. If not, we can expect to see the virus cropping up in many parts of the world, including here." (TT February 7, 2020) This external voice from the expert implicitly reveals the reporter's skeptical attitude towards the control efforts taken by China.

Besides, in NYT coverage on April 9, there are also some quotations from government officials, experts and American news outlets concerning China's fight against the outbreak and official statistics.

The NYT article, which has the title "China, Citing Fewer Cases, Tries to Rewrite Its Role in Crisis”, began by dismissing China's effort to defend itself against the American's effort to label the SARS-COV-2 virus as "the Wuhan Virus" or the "the Chinese virus" as government propaganda aimed at fending off international criticism, reinforcing the eco-destructive narrative of its title. It then admitted, "Voices from the World Health Organization to the Serbian government to the rapper Cardi B hailed China's approach as decisive and responsible.” However, the article immediately offsets any positive message that sentence may contain with the following paragraph:

But China could not savor the praise for long. In recent days, foreign leaders, even in friendly nations like Iran, have questioned China's reported infections and deaths. A top European diplomat warned that China's aid to the continent was a mask for its geopolitical ambitions, while a Brazilian official suggested the pandemic was part of China's plan to "dominate the world”. (NYT April 9, 2020)

Here the writer seemed to be only reporting and indirectly quoting what other people have said, but in reality she was choosing quotes to convey the message that she personally wanted to send to her readers. In the article which contains 1,429 words, the writer never bothered to give much more detail on those very eco- 
destructive accusations. She never revealed the names of the three people who she directly and indirectly quoted here, only mentioning in the 30th paragraph of her 33-paragaph long article that the Iran and Brazilian officials both retracted their comments later. But instead of interviewing those concerned about why the retractions were made, she offered the following information, "China is the biggest trading partner for both Iran and Brazil.” (NYT April 9, 2020) It is clear that writer is hoping her readers would reach the conclusion that China has used its economic clout to force its critics to shut up, without bothering to find out what actually happened.

The article included proper direct quotes from only three people, Hua Chunying, spokeswoman of China's Foreign Ministry; Bonnie Glaser, director of the China Power Project at the Center for Strategic and International Studies in Washington and Yanzhong Huang, head of the Global Health Center at Seton Hall University in New Jersey. Ms. Hua's quotes were taken from her press briefings, which means the reporter seemed to have only interviewed Ms. Glaser and Mr. Huang.

Ms. Glaser was quoted saying, "I think that the Chinese remain very fearful about what will happen when we finally all get on top of this virus, and there is going to be an investigation of how it started [...] They're just trying to repair the damage that was done very early on to China's reputation.” (NYT April 9, 2020) From this quote it seems that Ms. Glaser has already determined to blame China for the pandemic.

Mr. Huang, on the other hand, gave two quotes, one criticizing the US government, "the complacency, the lack of action, the efforts to downplay the serious of the problem by our own governments - we've seen these developments actually help China to make a strong case that they are not the cause of the problem.” (NYT April 9, 2020) His other quote was used as the last paragraph of the article, "History is unfortunately written by the victor, and the coronavirus outbreak is no exception.” (NYT April 9, 2020) Here although Mr. Huang, and the writer of the news article through him, seemed to accept that the US government has made many blunders in their response to the COVID-19 outbreak, they then reinforced their negative message of China that China is trying to change how the world sees the role it plays in the outbreak, and with the last quote from Mr. Huang they have left the impression that even if China is accepted as a positive force in the pandemic-combat effort in the end, it would only be because it has rewritten history, a strong reinforcement of the message conveyed in the article's title.

In journalistic writing, the writers are supposed to offer facts and not personal opinions or judgments. Journalism students and budding journalists were told that they should only offer facts and allow the readers to reach their own personal conclusions. Therefore, it is a norm in journalistic practice that external voices are quoted or reported in the coverage to make the information more credible and to guide the readers to draw the expected inference. And analysis of these external 
voices used in the data reveals that both TT and NYT make use of these external voices to direct the readers' attention and influence their perception of COVID-19 in China and China's fight against it.

\subsection{Characteristics of graduation resources}

Graduation system is concerned with up-scaling and down-scaling of meaning, which can be further divided into force and focus, each with its own sub-types, raise and lower in force and sharpen and soften in focus. It is found in the present study that force, which is associated with the degree of intensity, takes up a higher percentage in the data in both the two media, of which raise accounts for a higher percentage, as is shown in Table 5.

Table 5: Distribution of graduation resources.

\begin{tabular}{|c|c|c|c|c|c|c|}
\hline \multicolumn{3}{|l|}{ Sources } & \multicolumn{2}{|c|}{$\mathrm{TT}$} & \multicolumn{2}{|c|}{ NYT } \\
\hline & Type & & Number & Percent & Number & Percent \\
\hline Graduation & Force & Raise & 169 & $24.14 \%$ & 255 & $12.42 \%$ \\
\hline \multirow[t]{3}{*}{ Resources } & & Lower & 7 & $1.00 \%$ & 55 & $2.68 \%$ \\
\hline & Focus & Sharpen & 3 & $0.43 \%$ & 39 & $1.90 \%$ \\
\hline & & Soften & 0 & $0.00 \%$ & 36 & $1.75 \%$ \\
\hline Total & & & 179 & $25.57 \%$ & 385 & $18.75 \%$ \\
\hline
\end{tabular}

These graduation resources of force are used to express the reporter's attitude to either increase or decrease the "volume" of that attitude as evaluative prosodies are set up across the text (Martin and White 2005: 152). As is illustrated in Example (6) and Example (7) above, where such lexicogrammatical resources as "too," "effectively," and "increasingly" are employed before the negative appreciations "little," "late," "pointless," and "sophisticated” to realize graduation of up-scaling force to strengthen the reporter's negative attitude towards the China's measures taken to fight the COVID-19 pandemic and its "global propaganda machine".

\subsection{Analysis in the macro-evaluation system}

Before we come to the analysis of the objects and attributes involved in TT and NYT news coverage of the outbreak, we will discuss the measures taken by China to fight against the COVID-19 pandemic. 
Facing this crisis, the Communist Party of China and the Chinese government take people's life as the top priority, taking swift response and effective measures to fight against it, including locking down Wuhan to prevent and control the spread of the virus, constructing mobile hospitals as temporary treatment centers in Wuhan and later on in other virus-stricken cities to treat and cure the infected, mobilizing nationwide resources and dispatching national medical teams to assist the virus-stricken cities and reopening Wuhan by lifting its 76-day outbound traffic restrictions to bring the local work and daily life to normal and timely notifying the international community of the onset of the novel corona virus and sharing without reserve its experience in containing the spread of the virus and treating the infected. ${ }^{4}$ These anti-pandemic measures highlight the image of a major country with responsibility. Obviously, China has made significant contributions to the global fight against the epidemic. And these effective measures win plaudits from the international community, and in the words of Tedros Adhanom Ghebreyesus, the director-general of WHO:

The speed with which China detected the outbreak, isolated the virus, sequenced the genome and shared it with WHO and the world are very impressive, and beyond words. So is China's commitment to transparency and to supporting other countries. In many ways, China is actually setting a new standard for outbreak response. It's not an exaggeration. ${ }^{5}$

Analyzing the objects and attributes involved in the news coverage in the data, however, we find that neither TT nor NYT covers these measures positively, but instead both focus their attention more on the negative impact of China's measures against the outbreak. For example, due to the traffic restrictions of the lockdown of Wuhan, some people have to stay in other places during the Spring Festival, instead of returning to their homes. The two news outlets also blame the Chinese government for trying to conceal outbreak and the extent of it (NYT April 8 and April 9), not publishing death toll (TT and NYT April 8), giving incomplete official statistics (NYT February 7) and describe the restrictions on entering and leaving Hubei as "almost a humanitarian disaster" and the quarantine of Wuhan and other four cities as "unprecedented" in the modern history of epidemics (TT January 24-2, 24-4, NYT February 7). TT even stigmatizes China, calling the virus "Chinese mysterious virus," "Wuhan virus," and "China virus." Both news outlets often speak of the efforts and measures taken by China to contain and stem the spread

4 The State Council Information Office of the People's Republic of China. Fighting COVID-19: China in Action. http://www.xinhuanet.com/english/2020-06/07/c_139120424.htm (accessed 20 August 2020).

5 https://www.who.int/dg/speeches/detail/who-director-general-s-statement-on-ihremergency-committee-on-novel-coronavirus-(2019-ncov) (accessed 20 August 2020). 
very negatively, even distort and slander them and deny the achievements of China's fight against the COVID-19 pandemic. Judging in terms of the ecological orientations, we find that there are a lot of non-ecological factors in the coverage of China's fight against the COVID-19 pandemic in the two media, which goes, to a great extent, against the ecosophy of "diversity and harmony, interaction and coexistence" and the ideal of forging a global community with a shared future for all mankind, thus the news coverage in TT and NYT is eco-destructive.

\section{Conclusion}

The present study reveals the appraisal characteristics of the news coverage of COVID-19 in China in TT and NYT, the two mainstream Western media, and in turn throws some light on their position and interpretation of and attitude towards China's fight against it.

It is found that all the three sub-types of attitudinal resources are employed in the coverage in the two news outlets, among which judgment and appreciation resources are of a higher percentage, which reflects the journalistic pursuit of objectivity in news reports. However, the statistics also reveal that negative attitudinal resources are preferred to the positive ones and some aspects of the issues, that is to say, some objects and attributes, namely, the measures taken by China to fight against COVID-19 are ignored or distorted while others, for example, the possible negative impact of the measures is emphasized in the coverage of COVID-19 in China in the two news outlets. Such attribute agenda-setting reveals how the two news outlets think and talk about these issues. Analyzing in the macro-evaluation system in terms of ecological orientation, we find that the objects and attributes involved in the news coverage of TT and NYT are not covered comprehensively, that is, it goes against the ecosophy of "diversity and harmony, interaction and co-existence”, thus is eco-destructive agenda. Such news coverage may exert negative impact on the reader's cognition of China's fight against the pandemic and cause ecological damage and social injustice and is detrimental to the sustainable development of global ecological society and should therefore be resisted.

These findings have important implications for public perceptions of the major public health emergency and China's fight against the COVID-19 pandemic and in turn extend our understanding of how the news media influence and shape public opinion on the issues of the day. 
Research funding: This paper is funded by the Social Science Research Project of Jilin Province: An Ecolinguistic Study of News Discourse on Public Health Emergency (grant number 2020B201).

\section{References}

Alexander, Richard \& Arran Stibbe. 2014. From the analysis of ecological discourse to the ecological analysis of discourse. Language Sciences 41. 104-110.

Benoit, William L., Kevin A. Stein \& Glenn J. Hansen. 2005. New York Times coverage of presidential campaigns. Journalism \& Mass Communication Quarterly 82(2). 356-376.

Blakely, Debra E. 2003. Social construction of three influenza pandemics in the New York Times. Journalism \& Mass Communication Quarterly 80(4). 884-902.

Denham, Bryan E. 2014. Attribute agenda setting in the New York Times: The case of animal abuse in U.S. horse racing. Journalism \& Mass Communication Quarterly 91(1). 17-37.

Gao, Xiaohong \& Xijing Zhao. 2020. Tufa gonggong weisheng shijan zhong de zhuliu chuanbo de zeren yu shiming [Responsibility and mission of mainstream communication in public health emergencies]. Zhongguo Bianji [Chinese Editors Journal] (2-3). 4-9.

Haroon, Omair \& Syed Aun R. Rizvi. 2020. COVID-19: Media coverage and financial markets behavior - A sectoral inquiry. Journal of Behavioral and Experimental Finance 27. 1-5.

He, Wei \& Rong Wei. 2018. Duoyuan hexie, jiaohu gongsheng - guoji shengtai huayu fenxi zhi shengtai zhexueguan jiangou [Diversity and harmony, interaction and co-existence ecosophy for international ecological discourse analysis]. Waiyu Xuekan [Foreign Language Research] (6). 28-35.

He, Wei \& Zijie Ma. 2019. Shengtai yuyanxue shijiao xia de aodaliya zhuliu meiti zhi shijiuda baodao [News about the 19th NCCPC from the Australian mainstream media: An ecological linguistic approach]. Waiguo Yuwen [Foreign Language and Literature] 35(4). 1-9.

Huang, Guowen \& Ruihua Zhao. 2017. Shengtai huayu fenxi de yuanqi mubiao yuanze yu fangfa [On the origin, aims, principles and methodology of eco-discourse analysis]. Xiandai Waiyu [Modern Foreign Languages] 40(5). 585-596.

Hussin, A. Rothan \& Siddappa N. Byrareddy. 2020. The epidemiology and pathogenesis of coronavirus disease (COVID-19) outbreak. Journal of Autoimmunity. https://doi.org/10.1016/ j.jaut.2020.102433 (accessed 20 August 2020).

Jason, R. Silva \& Joel A. Capellan. 2019. A comparative analysis of media coverage of mass public shootings: Examining rampage, disgruntled employee, school, and lone-wolf terrorist shootings in the United States. Criminal Justice Policy Review 30(9). 1312-1341.

Kucharski, Adam J., Timothy W. Russell, Charlie Diamond, Yang Liu, John Edmunds, Sebastian Funk \& Rosalind M. Eggo. 2020. Early dynamics of transmission and control of COVID-19: A mathematical modelling study. The Lancet Infectious Diseases 20(5). 553-558.

Li, Junyi \& Zeshun You. 2020. Zhuanjia huayu de zhishi jiangou - guanyu xinguanfeiyan renshi de qujinhua fenxi [The proximization approach to the expert's discourse construction of COVID-19]. Tianjin Waiguoyu Daxue Xuebao [Journal of Tianjin Foreign Studies University] 27(4). 91-106.

Li, Xigen \& Yimu Zhang. 2020. Guoji tufa gonggong weisheng shijian de meiti baodao yuanze [Media reporting principles of international public health emergencies]. Duiwai Chuanbo [International Communications] (3). 72-74. 
Li, Yuelin \& Shanshan Wang. 2020. Mianxiang tufa gonggong weisheng shijian de xiangguan xinxi fabu tezheng fenxi [Identifying features of related information release when facing public health emergency]. Tushu yu Qingbao [Library \& Inforamtion] (1). 27-33, 50.

Li, Yuming \& Gaoqi Rao. 2020. yingji yuyan nengli jianshe chulun [On state emergency language competence]. Tianjin Waiguoyu Daxue Xuebao [Journal of Tianjin Foreign Studies University] 27(3). 2-13.

Li, Yuming, Shiju Zhao \& Lin He. 2020. "Zhanyi yuyan fuwu tuan” de shijian yu sikao [The practice of and reflections on "epidemic language service corps"]. Yuyan Zhanlüe Yanjiu [Chinese Journal of Language Policy and Planning] 5(3). 23-30.

Liu, Danqing, Zhiwei Feng, Hui Wang, Yuming Li, Chunhui Wang, Yin Fang, Shiju Zhao \& Bijuan Deng (eds.). 2020. Tufa gonggong shijian yuyan yingji duorentan [Forum on the role of language in responding to public emergencies]. [Special issue]. Yuyan Zhanlüe Yanjiu [Chinese Journal of Language Policy and Planning] 5(2). 5-14.

Lule, Jack. 2001. Daily news, eternal stories: The mythological role of journalism. New York: Guilford Press.

Lule, Jack. 2002. Myth and terror on the editorial page: The New York Times responds to September 11, 2001. Journalism \& Mass Communication Quarterly 79(2). 275-293.

Martin, James Robert \& David Rose. 2007. Working with discourse: Meaning beyond the clause, 2nd edn. London: Continuum.

Martin, James Robert \& Peter Robert Rupert White. 2005. The language of evaluation: Appraisal in English. London: Palgrave Macmillan.

McCombs, Maxwell. 2014. Setting the agenda: The mass media and public opinion. England: Polity Press.

Miao, Xingwei \& Ke Li. 2020. Kangji xinguanfeiyan yiqing yu gongtongti shenfen de huayu jiangou [Discursive construction of community identity in combating the outbreak of COVID-19]. Tianjin Waiguoyu Daxue Xuebao [Journal of Tianjin Foreign Studies University] 27(2). 88-99.

Miao, Xingwei \& Yun Zhao. 2019. Piping huayu fenxi de yicheng shezhi yu lujing yanjin [The agenda setting of CDA and evolution of research approaches]. Jiefangjun Waiguoyu Xueyuan Xuebao Vournal of PLA University of Foreign Languages] 42(5). 1-10.

Naess, Arne. 1995. The shallow and the long range, deep ecology movement. In Alan Drengson \& Yuichi Inoue (eds.), The deep ecology movement: An introductory anthology, 3-10. Berkeley, CA: North Atlantic Books.

Peng, Furong. 2020. Xinguanfeiyan yiqing fangkong beijing xia de zhonghua minzu rentong yu minzu zhuyi de yingdui [Identity to the Chinese nation and response to nationalism within the context of the prevention and control of COVID-19]. Minzu Xuekan [Journal of Ethnology] 11(1). $1-7$.

Petrosillo, Nicol, Giulio Viceconte, Onder Ergonul, Giuseppe Ippolito \& Eskild Petersen. 2020. COVID-19, SARS and MERS: Are they closely related? Clinical Microbiology and Infections 26(6). 729-734.

Stibbe, Arran. 2015. Ecolinguistics: Language, ecology and the stories we live by. London: Routledge.

Tian, Hailong. 2020. Zhongxiyi jiehe zhiliao xinguanfeiyan de huayu yanjiu: jiyu shuangceng wubu kuangjia de zhongxiyi huayu hudong fenxi [A discourse study of zhongyi-xiyi joint treatment of COVID-19: A "2-level 5-step" framework based analysis of the interaction between zhongyi and xiyi discourses]. Tianjin Waiguoyu Daxue Xuebao [ournal of Tianjin Foreign Studies University] 27(2). 128-139. 
Wang, Lifei \& Jiangwei Sun. 2020. Yiqing yinfa de yingji yuyan shuyu chengming yu yingyi [The nomenclature and English translation of emergency language services terminology under COVID-19 pandemic]. Tianjin Waiguoyu Daxue Xuebao Vournal of Tianjin Foreign Studies University] 27(3). 14-23.

Wang, Lifei, Mingyu Wang, Qi Shen, Ruohong Ma, Min Du, Xinlu Xu, Xuemei Zhang \& Siyuan Li (eds.). 2020. Yingji yuyan wenti duoren tan [Diverse views on issues concerning emergency language]. [Special issue]. Yuyan Zhanlüe Yanjiu [Chinese Journal of Language Policy and Planning] 5(3). 75-79.

Zhang, Wei \& Shaohua Wang. 2020. Xinguanfeiyan yiqing baodao zhong keyi yinyu de renzhili [The cognitive power of deliberate metaphors in the reports of COVID-19 outbreaks]. Tianjin Waiguoyu Daxue Xuebao [Journal of Tianjin Foreign Studies University] 27(2). 114-127. 